\title{
底面境界層に起因する潮汐残差流の生成構造
}

\section{STRUCTURE OF TIDE INDUCED RESIDUAL CURRENT CAUSED BY BOTTOM OSCILLATORY BOUNDARY LAYER}

\author{
高木不折**和田 清** \\ By Fusetsu TAKAGI and Kiyoshi WADA
}

\begin{abstract}
The structure of the vertical circulations caused by the combined effect of the bottom oscillatory boundary layer (Stokes layer) and bottom inclination in on-offshore directions have been analyzed theoretically. In the first-order theory, the maximum amplitude of water surface appears at the shallowest water depth of the reflection boundary in coastal region, and the major axes of hodograph deflect towards shallower water region. The generating terms of residual current in tidal currents with different distributions have been discussed. It has turned out that second-order vertical circulations show 2-layer structure. The results obtained through the discussion may give useful suggestions to investigate the generating mechanism of the tide induced residual currents in the coastal region.
\end{abstract}

Keywords: tide induced residual current, bottom boundary layer, sloping bottom

\section{1. 緒 論}

潮流の時間平均值である恒流（または残差流）は，閉 鎖性海域などでの物質輸送に大きな影響を及ぼすことは すでに周知のとおりである. 污濁予測としての物質輸送 モデルを精度高く確立するためには, 残差流の実態を把 握することが不可欠である，著者らは残差流の中でも最 も安定していると考えられている潮汐残差流の生成維持 機構に注目し, その解明に取り組んできた ${ }^{11}$.この残差 流の研究については, さまざまな生成維持機構が議論さ れているが22,3), 現地では, 陸岸沿いあるいは底面上の 境界層に起因する残差流が発達しやすいことが指摘され ている4).

振動流の境界層によって発生する定常流の問題は, す

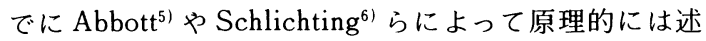
べられており, 安田 ${ }^{71-91}$ は, 一定水深の内湾において, 潮汐振動流の形成する境界層 (Stokes 層) が, 定常的 な水平・鉛直残差環流を生成することを示した.さらに, 図一1 のような海底地形が潮汐波の進行方向と垂直 (本 論文ではこの方向を岸沖方向とよぶことにする）に傾斜

\footnotetext{
* 正会員 工博 名古屋大学教授 工学部土木工学科 ( ₹464 名古屋市千種区不老町)

** 正会員 工修 名古屋大学助手 工学部土木工学科 (同上)
}

している場合に, 潮汐振動流による底面境界層と海底傾 斜の相互作用によって生じる水平循環流を求めてい $3^{10)}$. この傾斜海域における水平循環流は, 著者らも水 理実験により確認しているが ${ }^{11}$, 流速分布の水平・鉛直 シアーの構造が定量的によ゙のように関与しているのか は，明らかにされていないのが現状である.

また, 従来の取扱いでは, 潮汐波の進行方向にのみ水 面勾配を考虑し，それに垂直な岸沖方向については，水 面勾配を無視して取り扱っている.このことは, 潮流の 岸沖方向成分の存在および進行方向成分と鉛直成分の岸 沖方向変化を無視することに相当しており, 海域におけ る物質分散機構における一次元分散しかも鉛直シア一分 散のみを評価することに対応している.

一方, 実際の海域では, 湾口条件あるいは地形条件な ビによって水位変化は二次元的であり, また潮汐波の進 行方向に垂直な岸沖方向に海底傾斜が存在する場合に は, 潮汐波などの長周期波の波速は水深に依存するため に岸沖方向には異なるはずである. その結果, 流速の岸 沖方向成分の発生および進行方向と鉛直流速成分の岸沖 方向変化が生じることになる.しかし，この効果が岸沖 方向断面内における鉛直循環流によ゙のように影響し，一 次元分散の水平シアー分散さらには二次元分散に寄与す るかはまだ不明確のままである. 
本研究は，上述の点を明らかにする前段階として，潮 汐振動流によって形成される底面境界層に着目し, 岸沖 方向に海底傾斜が存在する海域を対象として,まず） 岸沖方向の水面勾配および流速成分, さらには他の流速 成分の岸沖方向変化を考慮し，それらがどのように岸沖 方向断面内における鉛直循環流の生成機構に寄与するの か, ii ）また, 流速の鈶直分布の違いによるその鉛直循 環流の生成機構, を理論的に解明しようとするものであ る.

\section{2. 潮汐残差流（定常流）の支配方程式}

\section{（1）基礎方程式}

対象とするモデル海域は, 図一1に示すように, 浅小 深 $h_{1}$ から沖（y方向）に向かって, 水深 $h$ が一定勾配 $\left(\tan \theta=h_{1} / y_{0}\right)$ で増加するような半無限領域の直線状 海岸である。このような状況は現実の湾では考えにくい が，基本的に海底傾斜がざのように流動場を規定し，残 差流の生成に寄与するのかを明らかにするために，一定 勾配をもつ海底地形という理想的な状況を設定した。ま た，長さスケールが $l$ のの海域に，潮汐波を含めた長 周期波の単一の基本成分波が， $x=0$ の境界より内部へ 進入するものとする. 本来, 領域内の陸岸と底面には境 界層が形成され，二次的な流れ場が生じる.しかし，こ こでは, 水平粘性は陸岸付近を除いて支配的ではないの で省略し, 鉛直粘性は底面境界層と傾斜面との複合効果 を評価するために考慮する.

したがって対象海域内の流れ場は，次のような方程式 に支配されていることになる.

$$
\begin{aligned}
& \partial \boldsymbol{V} / \partial t+(\boldsymbol{\nabla} \times \boldsymbol{V}) \times \boldsymbol{V}=-\boldsymbol{\nabla} x+\nu \partial^{2} \boldsymbol{V} / \partial z^{2} \cdots \cdots(1) \\
& \boldsymbol{\nabla} \cdot \boldsymbol{V}=0 \ldots \ldots \ldots \ldots \ldots \ldots \ldots \ldots \ldots \ldots \ldots \ldots \cdots \cdots(2)
\end{aligned}
$$

ここで, $\boldsymbol{V}(=\boldsymbol{i} u+j v+k w)$ : 流速ベクトル, $\boldsymbol{\nabla}=$ $i \partial / \partial x+j \partial / \partial y+k \partial / \partial z$ で, $\boldsymbol{i}, \boldsymbol{j}, \boldsymbol{k}$ はそれぞれ $x, y$, $\boldsymbol{z}$ 軸上の単位ベクトル, $\boldsymbol{\nabla} \times \boldsymbol{V}=\boldsymbol{i} \xi_{x}+\boldsymbol{j} \xi_{y}+\boldsymbol{k} \xi_{z}, \quad \xi_{x}=$ $\partial w / \partial y-\partial v / \partial z, \quad \xi_{y}=\partial u / \partial z-\partial w / \partial x, \quad \xi_{z}=\partial v / \partial x-$ $\partial u / \partial y, t$ : 時間, $\chi\left(=p / \rho+g z+V^{2} / 2\right)$ : 圧力, 位置 および運動エネルギーからなる全圧, $p$ : 圧力, $\rho$ : 密度, $g$ : 重力加速度, $\nu$ : 鉛直動粘性係数である.

一般に，式（1）および（2）を直接解くことは困難 であるので,ここでは, 解法としては正規モ一ド法" 従うことにする．すなわち，潮汐流のような長周期波動 場では, 流速成分，水位などの周期的な変数 $a$ は各調 和成分の和として以下のように表わすことができる。

$$
a=a_{s}+a_{T}+a_{T \tau}+\cdots \cdots+a_{n}+\cdots \cdots
$$

ただし，添字 $s$ は残差成分（1 周期平均）を示し，添字 $T$ は開口部から進入する潮汐波と同周期をもつ基本成 分, 添字 $T T$ は基本成分の 2 倍の周波数をもつ 2 倍周 波数成分, 添字 $n$ は $n$ 倍周波数成分を表わしている.

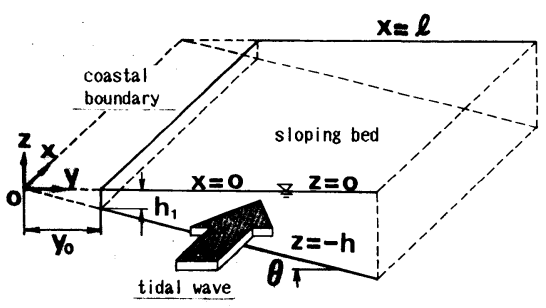

図一1 モデル海域

Schlichting ${ }^{6)}$ が解析したように，強い振動流の中に 弱い定常流が存在する場合には，基本振動モードが他の モードよりも十分に大きければ，小さいモードは攝動量 $\varepsilon\left(=\eta_{a} / h, \eta_{a}\right.$ : 水位振幅, $h$ : 水深 $)$ として扱われる. このようにすれば, 式（1）および（2）は, 各オーダー についての方程式群に書き換えられる. 本来, 各成分は, 多くの調和成分の非線形効果によって生成されるけれど $も^{9)}$, ここでは 1 次の基本成分によって生成される 2 次 の残差成分までに限定して取り扱うことにする.

こうして, 基本成分の方程式 (1 次のオーダー) とし ては,

$$
\begin{aligned}
& \partial u_{T} / \partial t=-g \cdot \partial \eta_{T} / \partial x+\nu \partial^{2} u_{T} / \partial z^{2} \cdots \cdots \cdots \cdots \cdots(4) \\
& \partial v_{T} / \partial t=-g \cdot \partial \eta_{T} / \partial y+\nu \partial^{2} v_{T} / \partial z^{2} \ldots \ldots \ldots \ldots \ldots(5) \\
& \partial \eta_{T} / \partial t+\partial\left(\int_{-h(y)}^{0} u_{T} d z\right) / \partial x+\partial\left(\int_{-n(y)}^{0} v_{T} d z\right) / \partial y=0
\end{aligned}
$$

が得られる.ここで, 海域の海水運動は, 密度が圧力の みで決まるバロトロピックな状態を想定して,$\chi_{T}=g \eta_{T}$ としている．また流速の鉛直成分 $w_{r}$ は，連続式（2） によって求まるものとする.

また，残差成分の方程式（2 次のオーダー）は以下の ようになる.

$$
\begin{aligned}
& \nu \partial^{3} u_{s} / \partial z^{3}= \partial\left(w_{T} \xi_{y T}-v_{T} \xi_{z T}\right)_{s} / \partial z \\
&+\partial\left(v_{T} \xi_{x T}-u_{T} \xi_{y T}\right)_{s} / \partial x \\
& \nu \partial^{3} v_{s} / \partial z^{3}= \partial\left(u_{T} \xi_{z T}-w_{T} \xi_{x T}\right)_{s} / \partial z \\
&+\partial\left(v_{T} \xi_{x T}-u_{T} \xi_{y T}\right)_{s} / \partial y \\
& \partial u_{s} / \partial x+\partial v_{s} / \partial y+\partial w_{s} / \partial z=0 \cdots \cdots
\end{aligned}
$$

本来 2 次以上の圧力項 $\chi_{T r}$ は, 未知関数であるが, 上式 からわかるように，渦度演算によってその項が消去され ている. そして, 式（7)，（8）および（9）によって, 流速の基本成分 (添字：T) が求まれば順次残差成分（添 字：s）を導くことができる.

ここで，2 倍周波数成分は残差成分と同じ項から生成 されるものであるが, 本研究の目的は, 残差成分の構造 を明らかにすることであるので，後者についてのみ取り 扱うことにする。

\section{（2） 1 次の基本成分の解法}

まず, 式（4)，（5）および（6）を解くことから始 
める. 従来の解析 ${ }^{10)}$ では, 1 次の流速の基本成分につい て, $x-z$ の鉛直断面内での二次元の運動方程式と流速 の $x$ 方向成分 $u_{\tau}$ を岸沖 $(y)$ 方向に積分した一次元の 連続式によって解くために, 水位 $\eta_{T}$ および流速 $u_{T}$ につ いては $y$ 方向の変化が考慮されていない. しかし, 本 研究で対象亡する現象では, 水位 $\eta_{T}$ は二次元的, かつ 流速 $u_{T}, v_{\tau}$ および $w_{T}$ は三次元的に解析する必要があ る.

そこで, 現在考えている水位 $\eta_{T}$ および流速 $u_{T}, v_{T}$, $w_{T}$ がすべて時間的に同じ周期運動をすると仮定する. すなわち,

$$
\begin{aligned}
& \eta_{T}=R_{e}[E(x, y) \cdot \exp (-i \omega t)] \cdots \cdots \\
& u_{T}=R_{e}[U(x, y, z) \cdot \exp (-i \omega t)] \cdot \\
& v_{T}=R_{e}[V(x, y, z) \cdot \exp (-i \omega t)] \cdot \cdot \\
& w_{T}=R_{e}[W(x, y, z) \cdot \exp (-i \omega t)]
\end{aligned}
$$

とおき，方程式（4)，（5）および（6）と境界条件を 満たすように, この $E, U, V$ および $W$ を求めること を考える.ここで, $E, U, V, W$ : 複素振幅, $\omega(=2$ $\pi / T)$ : 基本成分の角周波数, $T$ : 周期, $i(=\sqrt{-1})$ : 虚数である.

一方，境界条件は $\eta_{T}, u_{T}, v_{T}$ および $w_{T}$ について以下 のように設定する.

$$
\begin{aligned}
& \eta_{T}=\eta_{a} \cdot \cos \omega t ; \quad x=0, y=y_{0} \\
& \partial \eta_{T} / \partial x=0 \quad ; \quad x=l \text {. } \\
& \partial \eta_{T} / \partial y=0 \quad ; \quad y=y_{0} \\
& \partial u_{T} / \partial z=0 \quad ; \quad z=0 \\
& u_{T}=0 \\
& z=-h \\
& \partial v_{T} / \partial z=0 \\
& z=0 \text {. } \\
& v_{T}=0 \\
& w_{T}=0 \\
& z=-h \text {. } \\
& z=-h \text {. }
\end{aligned}
$$

これらの境界条件のうちで，やや特殊なものとなって いる式 $(11 \cdot \mathrm{a})$ について触れておこう. 一般に，湾のア スペクト比（湾幅／湾長）が十分小さい長方形湾では, 幅方向の水位変化は無視して扱われる. しかし, どの程 度のアスペクト比に対して, その仮定が成立するかは明 らかにされていないのが現状である. さらに，岸沖方向 に海底が傾斜する場合には,一様水深の場合とは異なり, たとえば，開口部 $(x=0)$ の境界で水位が岸沖方向に 一定であっても，潮汐波を含めた長周期波の波速が水深 に依存するために， $x$ 方向の波速は岸沖方向すなわち $y$ 方向に変化し, 沖方向に水位振幅が減衰して, 海岸付近 にエネルギーが trap されることが生じる(13),14).ここで は, 開口部での境界条件において，水位振幅あるいは位 相の差として，岸沖方向に水面勾配が生じる場合はもち ろん, 対象海域内の流れの内的な条件によって定まる, このような $y$ 方向の水面勾配を考えるものとして, 境 界条件式 $(11 \cdot a)$ が用いられている. その水面勾配の
一般形は, 式（4)，（5）および（6）の解によって定 まるが, その水面勾配の減衰の程度は, パラメーターに よって導入できるように考慮している.

まず，式（10）を式（4)，（5）および（6）に代入 すれば,以下のようになる.

$$
\begin{aligned}
& \nu \partial^{2} U / \partial z^{2}+i \omega U=g \partial E / \partial x \\
& \nu \partial^{2} V / \partial z^{2}+i \omega V=g \partial E / \partial y \\
& -i \omega E+\partial\left(\int_{-h(y)}^{0} U d z\right) / \partial x+\partial\left(\int_{-h(y)}^{0} V d z\right) / \partial y=0
\end{aligned}
$$

式 (15)，（16）を，境界条件式 (12)，（13）を考虑して 解くと, $U, V$ は $E$ の関数として表わされ, さらに, この関係を用いると 次式のように $E$ についての方程式となる.

$$
\begin{aligned}
& \partial^{2} E / \partial x^{2}+\alpha_{1}^{2} \partial^{2} E / \partial \phi^{2} \\
& \quad+\left(\alpha_{1}^{2} / \phi\right) \partial E / \partial \phi+\left(\omega^{2} / g \phi\right) E=0
\end{aligned}
$$

ここで, $\phi=\alpha_{1} y-\beta_{1}, \alpha_{1}=h_{1} / y_{0}, \beta_{1}=(1+i) /(2 \beta), \beta$ $=\sqrt{\omega / 2 \nu}$ としている.

$E=X(x) \cdot Y(y)$ と変数分離すれば, 式 (18) は, $X$ と $Y$ についての次の方程式に書き換えられる.

$$
\begin{aligned}
& d^{2} X / d x^{2}+k^{2} X=0 \\
& d^{2} Y / d \phi^{2}+(1 / \phi) d Y / d \phi-\left(K^{2}-Q^{2} / \phi\right) Y=0
\end{aligned}
$$

ここで, $Q^{2}=\omega^{2} / \alpha_{1}^{2} g, K^{2}=k^{2} / \alpha_{1}^{2}, k(=2 \pi / L)$ : 長周期 波の波数, $L$ : 波長である.

式（19）については，容易に解くことができるが，Y についての式 (20) は, 独立変数を $r=2 K \phi$ に変換し, また, 従属変数を $Y=e^{-r / 2} \cdot R(r)$ によって $R$ に変換 すると, Kummer の微分方程式に帰着する ${ }^{12)}$.

$$
r d^{2} R / d r^{2}+(1-r) d R / d r-\lambda R=0 \text {. }
$$

ここで, $r=2 k\left(y-\beta_{1} / \alpha_{1}\right), \lambda=(1-B) / 2, B=Q^{2} / K$ である。

ところで, 式(21) は第 3 項が整数の場合, すなわち, $m$ を 0 (基本モード) または正の整数（高次モード）と して

$$
\omega^{2}=g k(2 m+1) \tan \theta
$$

を満たす場合にのみ， $\eta_{T}$ が無限遠で減衰する解をもつ ことが知られている(13),14).こうして, 式 (19) および (21) の解を求めれば, 結局 $E$ に関する一般解は, 以下のよ うになる。

$$
\begin{aligned}
E= & \left(C_{1} e^{i k x}+C_{2} e^{-i k x}\right) \cdot e^{-r / 2} \\
& {\left[C_{3} F_{1}+C_{4}\left(F_{1} \cdot \ln r+F_{2}\right)\right] }
\end{aligned}
$$

ここで, $C_{i}(i=1 \sim 4)$ : 積分定数, $F_{1}\left[=F_{1}(\lambda, 1 ; r)\right]$, $F_{2}\left[=F_{2}(\lambda, 1 ; r)\right]:$ Kummer 合流型超幾何関数であ る（なお，式（23）中 $C_{4}$ の項を考虑しない場合には, エッジ波の場合 ${ }^{13)}$ と一致する).さらに, 式 (23) の未 定積分定数を境界条件式（11）を用いて決定すれば, 式 
（18）の無次元表示の解, $E^{*}$ が求められる.

$$
E^{*}=E / \eta_{a}=X_{2}^{*} \cdot \exp \left\{-\left(r-r_{0}\right) / 2\right\} \cdot C(r)
$$

ここで, $X_{2}^{*}=\cos k_{l}^{*}\left(1-x^{*}\right) / \cos k_{l}^{*}$

$C(r)=\left(f_{1} F_{10}-f_{20} F_{1}\right) /\left(f_{21} F_{10}-f_{20} F_{11}\right)$,

$f_{1}=F_{1} \cdot \ln r+F_{2}, \quad f_{21}=\left.f_{1}\right|_{r=r 0}$,

$f_{20}=\left.\left(d f_{1} / d r-f_{1} / 2\right)\right|_{r=r 0}$,

$F_{10}=\left.\left(d F_{1} / d r-F_{1} / 2\right)\right|_{r=r 0}$,

$F_{11}=\left.F_{1}\right|_{r=r 0}, \quad r=2 k_{y_{0}}^{*}\left(y^{*}-\beta_{1} / \alpha_{1} y_{0}\right)$,

$r_{0}=\left.r\right|_{y^{*}=1}, x^{*}=x / l, \quad k_{l}^{*}=k \cdot l$,

$y^{*}=y / y_{0}, \quad k_{y_{0}}^{*}=k \cdot y_{0}$,

である.

先述したように, $U, V$ は $E$ の関数であった.そこで, 式 $(24)$ で求められた $E^{*}$ を用いれば，無次元化した $U^{*}, V^{*}$ はそれぞれ以下のようになる.

$$
\begin{aligned}
U^{*}= & U /\left(g k \eta_{a} / \omega\right)=-i \cdot X_{1}^{*} \cdot C(r) \\
& \cdot \exp \left\{-\left(r-r_{0}\right) / 2\right\} \cdot G\left(z^{*}, h^{*}\right) \\
V^{*}= & V /\left(g k \eta_{a} / \omega\right)=-i \cdot X_{2}^{*} \\
& \cdot \exp \left\{-\left(r-r_{0}\right) / 2\right\} \cdot G\left(z^{*}, h^{*}\right) \\
& \cdot\{2 d C(r) / d r-C\} \cdots \cdots \cdots \cdots \cdots
\end{aligned}
$$

ここで, $X_{1}^{*}=\sin k_{l}^{*}\left(1-x^{*}\right) / \cos k_{l}^{*}$,

$$
\begin{aligned}
& G\left(z^{*}, h^{*}\right)=1-\exp \left\{-(1-i)\left(z^{*}+h^{*}\right)\right\}, \\
& z^{*}=\beta z, h^{*}=\beta h,
\end{aligned}
$$

である.ただし，式 (25)，(26) は， $G\left(z^{*}, h^{*}\right)$ にお いて, $\exp \left(-h^{*}\right) \doteqdot 0$ が成立するとみなせる $h^{*} \geqq 5$ の 範用に適用可能な近似解である.

こうして, 式 (15), (16) および (17) の解 $E, U$, $V$ が求められた。次に，無次元化した潮汐波の鉛直流 速成分の複素振幅 $W^{*}$ は，式 (25)，(26）を連続式 (2) に代入し，境界条件式（14）を考慮して定められる.

$$
\begin{aligned}
W^{*}= & W /\left(g k \eta_{a} / \omega\right)=-i \cdot X_{2}^{*} \\
& \cdot \exp \left\{-\left(r-r_{0}\right) / 2\right\} \alpha_{1}\left[\left(P_{2} / 4\right) \cdot H^{*}\right. \\
& \left.+\left\{P_{1} / 2-(1+i) \cdot P_{2} / 8\right\} \cdot G\left(z^{*}, h^{*}\right)\right]
\end{aligned}
$$

ここで, $H^{*}=z^{*}+h^{*}$

$$
\begin{aligned}
& P_{1}=2 \cdot\{2 d C(r) / d r-C\} \\
& P_{2}=16\left(k_{y_{0}}^{*} / h_{1}^{*}\right)\left(d^{2} C / d r^{2}-d C / d r\right) \\
& h_{1}^{*}=\beta h_{1}
\end{aligned}
$$

である.

なお，ここで注意すべきことは，式 $(23)$ の $C$ 、の項 を考慮しているために合流型超幾何関数は， $\lambda=0$ の場 合には $F_{1}=1$ となるが， $F_{2}$ は $r$ に関して増加関数とな る可能性がある．言い換えれば，前述した $\eta_{T}$ が沖 $(y)$ 方向に減衰する範囲を調べておく必要がある。

図一2 は式 $(24)$ の $k_{y 0}^{*}$ をパラメーターにして $x^{*}=$ 0 における $E^{*}$ の岸沖方向変化を示したものである. 同 図から， $k_{y 0}^{*} \leqq 0.5$ であれば $k \cdot y \leqq 1$ の範囲で $E^{*}$ が沖方 向に減衰することがわかる.

以上, 流速の基本成分の無次元振幅 $U^{*}, V^{*}$ および

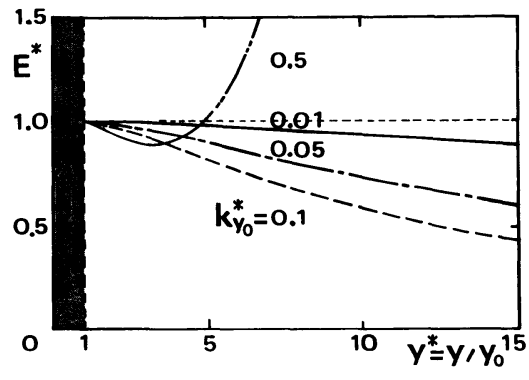

图一2 $\boldsymbol{k}_{\mathrm{s}}^{*}$ による無次元水位振幅 $E^{*}$ の $\boldsymbol{y}^{*}$ 方向变化 $\left(x^{*}=0\right)$

$W^{*}$ (式 $\left.(25) \sim(27)\right)$ が求められた。一例として $U^{*}$ の鉛直分布図を示すと，図一3の実線のようである．同 図から，境界層近傍に潮流の位相分布による振幅の膨ら み (hump) が生じていることがわかる。この振幅の膨 らみは，鉛直動粘性係数を定数としたことによって導か れたものである．このように，粘性のために底面上に発 達する層流境界層内の流速分布は，いわゆる shear wave となる．これは粘性が，1）流速振幅の減少と 2） 位相差を増す役割を果たしている。しかし，現実の海域， 特に振動する潮汐流中では, 時空間的に粘性率は変化し ているものと考えられる ${ }^{8)}$. 一般に，水深が $10 \sim 20 \mathrm{~m}$ の浅海域では，大部分が乱流状態であり，水面まで境界 層が発達していると考えてもよいことが多い.すなわち， 浅海域での乱流境界層は，河川などの一様流における境 界層之同じく，1）世ん断力分布が水面に向かって減少 する $\log$ linear layer と 2 ) log layer（これについては 底面上数 $\mathrm{m}$ まで constant stress layer の仮定がほぼ成 立することが実証されている）および 3 ) 厚さが数 $\mathrm{mm}$ 程度の粘性応力が支配的な粘性底層の三者によって表わ されるものとして取り扱われている(5).そこで，ここで はさらに，潮流の流速分布の鉛直構造の違い，すなわち 渦度変化がざのように鉛直循環流の生成機構に関係して いるかを考察するために，図一3の破線で示したような， 潮流の振幅の鉛直分布が膨らみをもたない（全水深にわ たって鉛直シアーが同符号である）場合についても，流 速の基本成分の無次元振幅を求めておこう。この位相の 分布を無視した流速の鈶直分布形状は，第 1 段階として 絶対値はともかく現実の海域で一般的な状態を考えてい

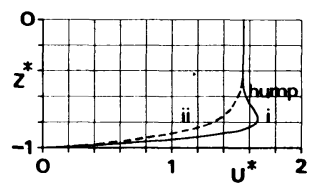

图一3 基本流速分布の無次元振幅 $U^{*}$ の鉛直方向変化 $\left(x^{*}=0\right.$, $\boldsymbol{y}^{*}=2$ )

1）膨らみ (hump) のある場合

ii）膨らみ (hump) のない場合 
ることに相当しているものと思われる.

この場合, 式 (25) （27）において, 潮流の鉛直分布 を表わす $G\left(z^{*}, h^{*}\right)$ を, $G^{\prime}\left(z^{*}, h^{*}\right)=1-\exp \left\{-\left(z^{*}\right.\right.$ $\left.\left.+h^{*}\right)\right\}$ とし, 流速の基本流速成分の無次元振幅 $U^{\prime *}$, $V^{*}$ および $W^{*}$ を求めると, 以下のようである.

$$
\begin{aligned}
U^{\prime *}= & U^{\prime} /\left(g k \eta_{a} / \omega\right)=-i \cdot X_{1}^{*} \cdot C(r) \\
& \cdot \exp \left\{-\left(r-r_{0}\right) / 2\right\} \cdot G^{\prime}\left(z^{*}, h^{*}\right) \cdots \\
V^{\prime *}= & V^{\prime} /\left(g k \eta_{a} / \omega\right)=-i \cdot X_{2}^{*} \\
& \cdot \exp \left\{-\left(r-r_{0}\right) / 2\right\} \cdot G^{\prime}\left(z^{*}, h^{*}\right) \\
& \cdot\{2 d C(r) / d r-C\} \cdots \cdots \cdots \cdots \cdots \cdots \\
W^{\prime *}= & W^{\prime} /\left(g k \eta_{a} / \omega\right)=-i \cdot X_{2}^{*} \\
& \cdot \exp \left\{-\left(r-r_{0}\right) / 2\right\} \alpha_{1}\left[\left(P_{2} / 4\right) \cdot H^{*}\right. \\
& \left.+\left\{P_{1} / 2-P_{2} / 4\right\} \cdot G^{\prime}\left(z^{*}, h^{*}\right)\right] \cdots \cdots \cdots
\end{aligned}
$$

\section{（3） 2 次の残差成分の解法}

海域における物質の長期的な分散効果としては，厳密 には残差流の三次元的な構造 $\left(u_{s}, v_{s}\right.$ および $\left.w_{s}\right)$ が, 関与しているはずであるが，本研究では岸沖方向の流速 成分などが，その方向の断面内における鉛直循環流の形 成にどのようにかかわっているかを明らかにするという 物理的な観点に立っている. 以下では，その前段階とし て, 特に, 岸沖方向についての潮汐残差流 $v_{s}$ の生成要

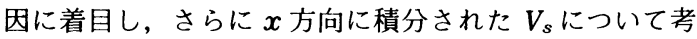
えることにする．このように考えて，2 次の残差成分 $v_{s}$ についての式（8）に対する境界条件は次式のように与 える.

$$
\begin{aligned}
& z^{*}=-h^{*}\left(y^{*}\right) ; \quad V_{s}^{*}=\int_{o}^{l} v_{s}^{*} d x=0 \\
& z^{*}=0 \quad ; \quad d V_{s}^{*} / d z^{*}=0 \ldots \ldots \\
& \int_{0}^{l}\left(\int_{-h}^{0} v_{s}^{*} d z^{*}\right) d x=0 \ldots \ldots \ldots \ldots \ldots \ldots \ldots \ldots \ldots \ldots
\end{aligned}
$$

ここで， $v_{s}^{*}=v_{s} /\left(\left(g k \eta_{a} / \omega\right)^{2} \cdot \alpha_{1} \beta l / \omega\right)$ である. すなわち， 、) 底面で流速が 0,2$)$ 水面で応力が 0,3$)$ 断面流量が 0 , である.

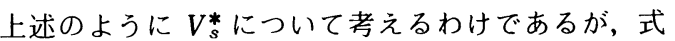

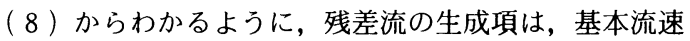
成分のシアー（流れの横方向勾配）を表わす右辺 2 項か ら成り立っている. 式 (8) に境界層近似を適用し,さ らに式 (27) の $W^{*}$ は， $\alpha_{1}$ あるいは $k \cdot h$ のオーダーで あることから， $\partial\left(w_{T} \cdot \partial w_{T} / \partial y\right) / \partial z, \partial\left(v_{T} \cdot \partial w_{T} / \partial y\right)$ $/ \partial y$ および $\partial\left(u_{r} \cdot \partial w_{T} / \partial x\right) / \partial y$ の項は, 他項に比べて 省略することができる．このため，残差流生成に寄与す る項は以下のように簡略化できる.

$$
\begin{aligned}
\nu \partial^{3} v_{s} / \partial z^{3}= & {\left[\partial\left(u_{\tau} \cdot \partial v_{\tau} / \partial x\right) / \partial z\right.} \\
& +\partial\left(w_{r} \cdot \partial v_{\tau} / \partial z\right) / \partial z \\
& \left.+\partial\left(v_{\tau} \cdot \partial v_{\tau} / \partial z\right) / \partial y\right]_{s}
\end{aligned}
$$

このように, オーダー的に残差成分に寄与するのは, 右 辺第(1)項（基本流速成分 $v_{T}$ の水平シアーと $u_{T}$ の相互 作用), 第(2)項 (水面の昇降 $\left[w_{T}\right.$ の存在 $]$ 亡 $v_{T}$ の鉛直
アーの相互作用) および第(3)項（ $v_{T}$ の鈆直シアーとそ れ自身の相互作用) である.

さて，式（32）を境界条件式（31）のもとで解くわけ であるが，潮流の基本成分の鉛直分布の差異による岸沖 方向の鉛直循環流の生成機構の変化について明らかにす るために，まず，潮流の基本流速成分の振幅が鉛直方向 に膨らみをもつ場合（図一3の実線）について残差流を 求めよう.

すなわち, 残差流 $V_{s}^{*}$ の構造を, 式 (32) の右辺第(1), (2)および(3)項おのおのによるもの $\left(V_{s 1}^{*}, V_{s 2}^{*}, V_{s 3}^{*}\right)$ の 和として,

$$
V_{s t}^{*}=V_{s 1}^{*}+V_{s 2}^{*}+V_{s 3}^{*}
$$

と表わせば，この各項は以下のように算定される.

$$
\begin{aligned}
& V_{s 1}^{*}=V_{s 1} /\left(\left(g k \eta_{a} / \omega\right)^{2} \cdot \alpha_{1} \beta l / \omega t\right. \\
& =(1 / 4) \cdot A \cdot\left(P_{1} / 2\right) \cdot \exp \left\{-\left(r-r_{0}\right)\right\} \\
& \cdot \int_{0}^{1} X_{1}^{*} d x^{*}\left[4 \exp \left(-H^{*}\right) \cdot \sin \left(H^{*}\right)+\exp \left(-2 H^{*}\right)\right. \\
& +(3 / 2)\left(z^{*} / h^{*}\right)^{2} \cdot\left(-1+5 /\left(2 h^{*}\right)\right) \\
& \left.+\left(1 / 2-15 /\left(4 h^{*}\right)\right)\right] \\
& V_{s 2}^{*}=V_{s 2} /\left(\left(g k \eta_{a} / \omega\right)^{2} \cdot \alpha_{1} \beta l / \omega\right\} \\
& =(1 / 8) \cdot\left(P_{1} / 2\right) \cdot \exp \left\{-\left(r-r_{0}\right)\right\} \\
& \cdot \int_{0}^{1} X_{2}^{*} d x^{*}\left[-2\left(P_{1}+P_{2}\right) \exp \left(-H^{*}\right) \cdot \sin \left(H^{*}\right)\right. \\
& +\left(2 P_{1}-P_{2}\right) \exp \left(-H^{*}\right) \cdot \cos \left(H^{*}\right) \\
& -P_{1} \cdot \exp \left(-2 H^{*}\right) \\
& -P_{2} \cdot H^{*} \exp \left(-H^{*}\right) \cdot\left\{\sin \left(H^{*}\right)-\cos \left(H^{*}\right)\right\} \\
& -(3 / 2)\left(z^{*} / h^{*}\right)^{2} \cdot\left(P_{1}-P_{2}+\left(P_{1}+4 P_{2}\right) /\left(2 h^{*}\right)\right) \\
& \left.+\left(P_{1}-P_{2}\right) / 2+3\left(P_{1}+4 P_{2}\right) /\left(4 h^{*}\right)\right] \text {. } \\
& V_{s 3}^{*}=V_{s 3} /\left\{\left(g k \eta_{a} / \omega\right)^{2} \cdot \alpha_{1} \beta l / \omega\right\} \\
& =(1 / 4) \cdot\left(P_{1} / 2\right) \cdot \exp \left\{-\left(r-r_{0}\right)\right\} \\
& \cdot \int_{0}^{1} X_{2}^{*} d x^{*}\left[\left(-P_{1}+P_{2}+4 A\right) \cdot \exp \left(-H^{*}\right)\right.
\end{aligned}
$$$$
\cdot \sin \left(H^{*}\right)+P_{1} \exp \left(-H^{*}\right) \cdot \cos \left(H^{*}\right)+\left(P_{2}+4 A-2 P_{1}\right)
$$$$
/ 4 \cdot \exp \left(-2 H^{*}\right)+(3 / 2)\left(z^{*} / h^{*}\right)^{2} \cdot\left\{-\left(2 P_{1}+P_{2}\right.\right.
$$$$
\left.+4 A) / 4+\left(-2 P_{1}+5 P_{2}+20 A\right) /\left(8 h^{*}\right)\right\}
$$$$
+\left\{\left(2 P_{1}+P_{2}+4 A\right) / 8\right.
$$$$
\left.\left.-3\left(-2 P_{1}+5 P_{2}+20 A\right) /\left(16 h^{*}\right)\right\}\right]
$$

ここで, $A=C \cdot k_{y_{0}}^{*} / h_{1}^{*}$ である.

次に，潮流の鉛直分布か膨らみをもたない場合（図一 3 の破線）については，同様に以下のように表わすこと ができる.

$$
\begin{aligned}
& V_{s t}^{\prime *}=V_{s 1}^{\prime *}+V_{s 2}^{\prime *}+V_{s 3}^{\prime *} \\
& V_{s 1}^{\prime *}=V_{s 1}^{\prime} /\left(\left(g k \eta_{a} / \omega\right)^{2} \cdot \alpha_{1} \beta l / \omega\right) \\
& =(1 / 4) \cdot A\left(P_{1} / 2\right) \cdot \exp \left\{-\left(r-r_{0}\right)\right\} \\
& \cdot \int_{0}^{1} X_{1}^{*} d x^{*}\left[-8 \cdot \exp \left(-H^{*}\right)+\exp \left(-2 H^{*}\right)\right. \\
& \left.+(3 / 2)\left(z^{*} / h^{*}\right)^{2} \cdot\left(7-15 /\left(2 h^{*}\right)\right)+\left(-7 / 2+45 /\left(4 h^{*}\right)\right)\right]
\end{aligned}
$$




$$
\begin{aligned}
& V_{s 2}^{\prime *}=V_{s 2}^{\prime} /\left\{\left(g k \eta_{a} / \omega\right)^{2} \cdot \alpha_{1} \beta l / \omega\right\} \\
& =(1 / 8) \cdot\left(P_{1} / 2\right) \cdot \exp \left\{-\left(r-r_{0}\right)\right\} \\
& \cdot \int_{0}^{1} X_{2}^{*} d x^{*}\left[4\left(P_{1}-P_{2}\right) \cdot \exp \left(-H^{*}\right)\right. \\
& -\left(P_{1}-P_{2} / 2\right) \cdot \exp \left(-2 H^{*}\right) \\
& +2 P_{2} \cdot\left(H^{*}+3\right) \cdot \exp \left(-H^{*}\right) \\
& +(3 / 2)\left(z^{*} / h^{*}\right)^{2} \cdot\left(-\left(6 P_{1}+5 P_{2}\right) / 2\right. \\
& \left.+\left(14 P_{1}+17 P_{2}\right) /\left(4 h^{*}\right)\right)+\left(6 P_{1}+5 P_{2}\right) / 4 \\
& \left.-3\left(14 P_{1}+17 P_{2}\right) /\left(8 h^{*}\right)\right] \\
& V_{s 3}^{\prime *}=V_{s 3}^{\prime} /\left\{\left(g k \eta_{a} / \omega\right)^{2} \cdot \alpha_{1} \beta l / \omega\right\} \\
& =(1 / 4) \cdot\left(P_{1} / 2\right) \cdot \exp \left\{-\left(r-r_{0}\right)\right\} \\
& \cdot \int_{0}^{1} X_{2}^{*} d x^{*}\left[-2\left(-P_{1}+P_{2}+4 A\right) \cdot \exp \left(-H^{*}\right)\right. \\
& -\left(-P_{2}-4 A+2 P_{1}\right) / 4 \cdot \exp \left(-2 H^{*}\right) \\
& +(3 / 2)\left(z^{*} / h^{*}\right)^{2} \cdot\left\{\left(-6 P_{1}+7 P_{2}+28 A\right) / 4\right. \\
& \left.-\left(-14 P_{1}+15 P_{2}+60 A\right) /\left(8 h^{*}\right)\right\} \\
& -\left(-6 P_{1}+7 P_{2}+28 A\right) / 8 \\
& \left.+3\left(-14 P_{1}+15 P_{2}+60 A\right) /\left(16 h^{*}\right)\right]
\end{aligned}
$$

なお， $k_{y 0}^{*} \ll 1$ であれば， $P_{1} \gg P_{2}, A$ となるので, 詳し く検討すると，潮流の鉛直分布が膨らみをもつ，もたな いにかかわらず式（33）（40）の残差流の生成は, 主と して式 (32) の右辺第(2), (3)項に依存していることがわ かる.

\section{3. 解析結果の考察}

1 次および 2 次の解析解において，その支配パラメー 夕一は, $k_{l}^{*}, k_{y 0}^{*}, \alpha_{1}(=\tan \theta), h_{1}^{*}$ の 4 つである. 計算 はこれらのパラメーターを種々変化させた 64 ケースに ついて行ったが，その一例を図一4に示す。この図は, $k_{l}^{*}=1, k_{y 0}^{*}=0.01, h_{1}^{*}=5, \alpha_{1}=\tan \theta=1 / 100$ の場合につ

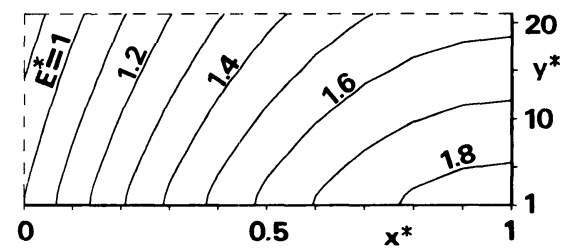

（a）無次元水位振幅 $E^{*}$ の水平分布

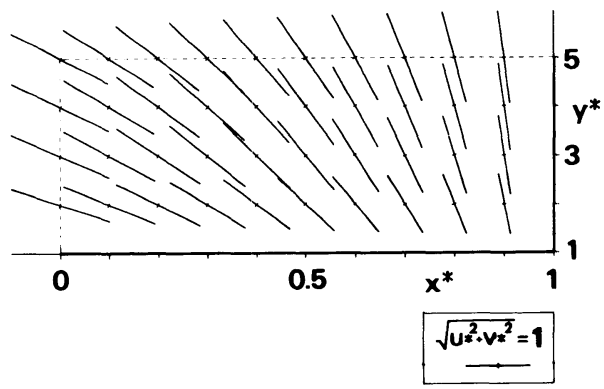

（b） 水面 $\left(z^{*}=0\right)$ における基本流速の棈円長軸 図-4
いて, 無次元水位振幅 $E^{*}$ の水平分布 (a 図), 水面に おける無次元基本流速成分 $U^{*}, V^{*}$ の楕円長軸（b 図） を示している. 現実の問題では, 水位変化はかなり緩や かとなるが, 図一4はあえて水位変化の状況を誇張して 計算したものである。同図 a のように，沿岸から $y^{*}$ 方 向に離れるほど潮汐波の振幅は減少し，そのエネルギ一 が海域内に封じ込められる trapped mode となり，海域 奥浅水部 $\left(x^{*}=1, y^{*}=1\right)$ で水位の最大振幅が生じる. 一方，図 b からわかるように，潮流棈円の長軸は海域奥 浅水部に向かって偏向する.なお，2.（2）で述べたよ うに，水位が沖方向に減衰する trapped mode となるか 否かは， $k_{y 0}^{*}$ が重要なパラメーターであることを付記す る.

さらに，図一5は，図-4 と同じ条件において，図一3 に示したように，潮流の基本流速成分 $U, V$ および $W$ の振幅が鉛直方向に膨らみをもつ場合（図一3実線）と もたない場合（図一3破線）に，それらによって生成さ れる残差流の鉛直分布を式 (32) の生成項別に示したも のである.なお, 図中の残差流 $V_{s}^{*}$ は, $x^{*}$ 方向に $x^{*}=$ 0〜1まで積分した值である.

まず，前者の場合， $w_{T}$ と $v_{T}$ の鉛直シアーの相互作用 (式 (32)，第(2)項）および $v_{T}$ の鉛直シアーとそれ自身 の相互作用(第(3)項)によって生じる残差流 $V_{s 2}^{*}, V_{s 3}^{*}$ は, 表層から中層付近では，正符号すなわち深水域に向かう 沖方向流が，底層付近ではその流れを補償する負符号の 岸方向流が生じて, 残差流の 2 層構造をしていることが わかる.

一方, 同図 $(\mathrm{i})$ で, $v_{T}$ の水平シア一と $u_{T}$ の相互作 用 (式 (32)，第(1)項) による鉛直分布 $V_{s 1}^{*}$ は， 3 層構 造をしていることを示している. すなわち， $O\left(k_{y_{0}}^{*}\right)$ で あるので, オーダー的には小さいものの, 底層と表層で 岸方向流が生じており, それらの中間部で連続条件（残 差成分は鈶直断面平均０）によってバランスする中層の 流れ（神方向流）が生じる.

以上, 3 成分の合成としての $V_{s t}^{*}$ は, 同図（iv）のよ うに，底層で岸方向，表層で沖方向流となる残差流の 2 層構造をしている.

次に，潮流の基本成分の振幅が鉛直方向に膨らみをも たない場合（図一5（b ））には, 以下の点を除いて膨ら みをもつ場合と同様の潮汐残差流となる.

すなわち， $v_{T}$ の水平シアーと $u_{T}$ の相互作用による $V_{s 1}^{\prime *}$ の鉛直分布（同図（i ））は，上述の 3 層構造では なく，他の場合（同図（ii），（iii））と同様の 2 層構造 をしており，オーダ一的には，膨らみをもたない場合の 方が大きい.この場合の合成した残差流についてみると, 残差流が岸沖方向に移動しない中立点は, 膨らみをもた ない場合 $\left(V_{s t}^{\prime *}\right)$ には，水深のほぼ中央に位置するのに 

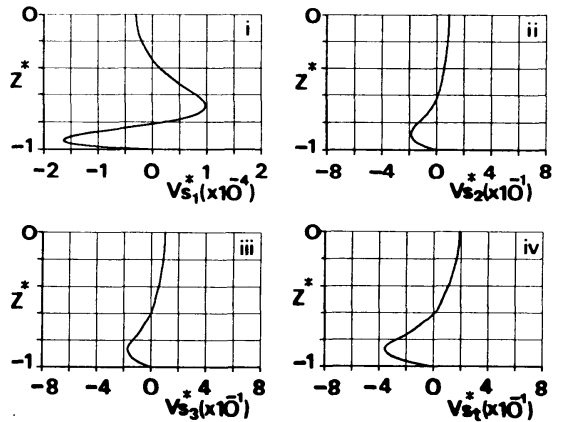

（a ）基本流速成分の振幅が鈶直方向に膨らみをもつ場合
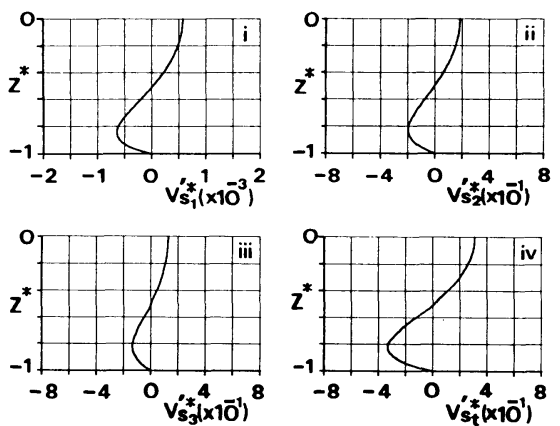

（b）基本流速成分の振幅が鈆直方向に膨らみをもたない場合

図-5 生成項別による無次元岸沖方向残差成分 $\left(x^{*}\right.$ 方向樌分) $V_{s}^{*}$ の鉛直分布 $\left(y^{*}=2\right)$

対し，膨らみをもつ場合 $\left(V_{s t}^{*}\right)$ には，その中央よりも やや底面より (水面下 6 割程度) に位置している。この ように, 中立点の位置が低いと, 特に, 底面せん断応力 の定常成分の増大を生じ，境界層内における長期的な物 質分散により大きく寄与するものと考えられる.

全体としては，潮流の基本成分の振幅が鉛直方向に膨 らみをもつ，もたないにかかわらず， $x^{*}$ 方向に積分し た残差流 $\left(V_{s t}^{*}, V_{s i}^{\prime *}\right)$ は, 底層で岸方向流，表層で沖方 向流の 2 層構造をしていることがわかった.

さらに, $y-z$ 断面内で $x$ 方向に $0 \sim l$ まで積分した残 差流成分の連続式から， $V_{s t}^{*}\left(V_{s t}^{*}\right)$ とバランスする $W_{s t}^{*}$ $\left(W_{s i}^{*}\right)$ が求められる. この $V_{s t}^{*}, W_{s t}^{*}$ の合成として, そ の断面内では，底層で岸方向流，表層で沖方向流となる 2 層の残差流構造が現われ，浅水域で上昇する鉛直循環 流の存在が示された。

従来, 海域における鉛直的な循環流は, 密度流や吹送 流であるとされていたが8)，岸沖方向に海底傾斜が存在 する場合には，安田 ${ }^{10)}$ の指摘した潮汐波の進行方向 $(x$ 方向）に対する水平循環流のほかに, 流速成分 $v_{T}$ の水 平・鉛直シアーによる岸沖方向の鉛直循環流も，海域の 長期的な物質分散に寄与する重要な要素であると考えら れる.

\section{4. 結 論}

以上，潮汐波の進行方向に対して垂直（岸沖方向）に 海底が傾斜した海域において, 従来の解析解では無視し て扱われていた岸沖方向の水面勾配と流速成分 $v_{T}$ を考 慮し, その水平・鉛直シア一と各流速成分の相互作用に よって生じる残差流 $V_{s}^{*}$, 生成項別に取り上げて, 潮 流の基本成分の振幅分布いかんによる $V_{s}^{*}$ の鉛直分布の 違いについて述べた．得られた結論を列挙すれば以下の ようである.

（1）潮汐波は, trapped mode となる $\tan \theta=1 / 100$ では，海域奥浅水部で水位の最大振幅が生じ，基本流速
成分の楕円長軸はその方向へ偏向する.

（2）残差流の生成項別の鉛直分布を求めた結果，ま す，潮流の基本成分の振幅が，鉛直方向に膨らみをもつ 場合, $u_{T}$ と $v_{T}$ の水平シア一の相互作用による項は, オ一 ダ一的には小さいものの, 表層および底層付近で岸方向 流，その中層で沖方向流という 3 層構造となり得ること を示した. しかし， $w_{T}$ と $v_{T}$ の鉛直シアーの相互作用に よる項および $v_{T}$ の鉛直シアーとそれ自身の相互作用に よる項の残差流は，同程度の大きさで，その鉛直分布は 底層で岸方向流, 表層で沖方向流の 2 層構造をしている.

（3）一方，潮流の基本成分の振幅が，鉛直方向に膨 らみをもたない場合には， $u_{T}$ と $v_{T}$ の水平シア一の相互 作用による項は，他の場合と同様 2 層構造をしており， 膨らみをもつ場合に比べて，そのオーダーは大きい．

（4）また,残差流が岸沖方向に移動しない中立点は, 振幅の膨らみがある場合には，ない場合に比へ，低い位 置となり，底面せん断応力の定常成分が大きくなる.

（5）全シアーを含んだ残差流 $V_{s}^{*}$ の鈆直分布は, 潮 流の基本成分が，鉛直方向に膨らみをもつ，もたないに かかわらず，底層で岸方向流，表層で沖方向流之なる 2 層構造をしており，浅水域で上昇する鉛直循環流が存在 し得る.

一般に潮流は鉛直および水平的にシアーをもってお り，潮汐波の進行方向と垂直に海底傾斜が存在する場合 には，潮汐波は常にその進行方向之岸沖方向に水平・鉛 直的な残差環流を生成する潜在力をもっているといえ る. 実際には，鉛直循環流が形成されるには密度分布， 水平・鉛直的な乱れ, 湾の水深や幅の変化, 海面を吹く 風，地形による擾乱，さらには水平的な残差流との相互 作用などさまざまな影響を受けるので8)，潮汐による鈆 直循環流を現地観測の中で定量化することは困難と思わ れるが，今後より詳細な検討を重ね，湾内に生じる潮汐 残差流の生成・維持機構, さらにそれに及ぼす地形条件 の影響を明らかにしていきたいと考えている. 
最後に，本研究を進めるに際し，終始適切なご助言を 頂いた, 名古屋大学工学部土木工学科 岩田好一朗教授 に深く感謝の意を表します。

\section{使用記号表}

$C_{i}$ : 積分定数 $(i=1 \sim 4)$

$E:$ 水位 $\eta$ の複素振幅

$E^{*}: E$ の無次元複素振幅

$F_{1}, F_{2}:$ Kummer $の$ 合流型超幾何関数

$g:$ 重力加速度

$h:(=h(y))$ 水深

$h_{1}$ : 浅水深

$i:(=\sqrt{-1})$ 虚数

$k:(=2 \pi / L)$ 長周期波の波数

$L$ : 長周期波の波長

$l:$ 海域の長さスケール

$m$ :。(基本モード) または正の整数（高次モード）

$p$ :圧力

$T:$ 長周期波の周期

$U:$ 流速成分 $u$ の複素振幅

$U^{*}: U$ の無次元複素振幅 (with hump)

$U^{* *}: U$ の無次元複素振幅 (no hump)

$\boldsymbol{V}:(=\boldsymbol{i} u+\boldsymbol{j} v+\boldsymbol{k} w)$ 流速ベクトル

$V:$ 流速成分 $v$ の複素振幅

$V^{*}: V$ の無次元複素振幅 (with hump)

$V^{\prime *}: V$ の無次元複素振偪 (no hump)

$v_{s}^{*}$ : 無次元化した残差流の $y$ 方向成分

$V_{s}^{*}: x$ 方向に0〜 $l$ まで積分した $v_{s}^{*}$

$W$ : 流速成分 $w$ の複素振幅

$W^{*}: W$ の無次元複素振幅 (with hump)

$W^{* *}: W$ の無次元複素振幅 (no hump)

$\boldsymbol{\nabla} \times \boldsymbol{V}:\left(=\boldsymbol{i} \xi_{x}+\boldsymbol{j} \xi_{y}+\boldsymbol{k} \xi_{z}\right)$ 渦度ベクトル

$\alpha_{1}:(=\tan \theta)$ 海底勾配

$\beta:(=\sqrt{\omega / 2 \nu})$ 境界層厚の逆数

$\varepsilon$ : 㠌動量

$\eta_{a}$ : 湾口部 $(x=0)$ における水位振幅

$\nu$ : 鉛直動粘性係数（一定）

$\rho:$ 海水の密度

$\chi$ ：圧力，位置および運動エネルギーからなる全圧 $\omega:(=2 \pi / T)$ 長周期波の角周波数

[添 字]

$s$ : 長周期波の残差 (1 周期平均) 成分を示す.
$T ：$ 長周期波の基本成分を示す.

$T T$ : 長周期波の 2 倍周波数成分を示す.

$n$ : 長周期波の $n$ 倍周波数成分を示す.

*：無次元量を示す。

' : 潮流の鉛直分布が膨らみをもたない場合（no hump）の諸量を示す.

$t:$ 残差成分の総量を示す.

\section{参 考 文 献}

1）たとえば，和田 清・中村俊六：知多湾における海水流 動機構に関する実験的研究, 第 30 回海岸工学講演会論文 集, pp. 521 525, 1983.

2) Johns, B. : Physical Oceanography of Coastal and Shelf Seas, Elsevier, pp. 321 356, 1985.

3) van de Kreeke, J. : Physics of Shallow Estuaries and Bays, No.16, Springer-Verlag, pp. 42 129, 1986.

4）安田秀一：剝離による潮汐残渣流に関する実験的研究, 中国工業技術試験所報告, No. 10, pp. 53 69, 1980.

5) Abbott, M. R. : Boundary Layer Effects in Estuaries, Journal of Marine Research, Vol. 18, pp. 83 100, 1960.

6) Schlichting, H. : Boundary Layer Theory, 6 th ed., McGraw-Hill, 1966.

7) 安田秀一：陸岸境界層による潮汐残渣流に関する理論的 研究，中国工業技術試験所報告，No. 12，pp. 1 15, 1980.

8）安田秀一：密度の均質な湾内の潮汐による鉛直循環流, 中国工業技術試験所報告, No. 16, pp. 21 40, 1982.

9）安田秀一：境界層による潮汐残渣流系一一の方程式之 湾長が任意の場合の解一，中国工業技術試験所報告, No. 19 , pp. $67 \sim 86,1983$.

10) Yasuda, H. : Horizontal Circulation Caused by the Bottom Oscillatory Boundary Layer in a Bay with a Sloping Bed, Journal of Oceanography Society of Japan, Vol.40, pp. 124 134, 1984.

11）高木不折・和田 清 : 海底傾斜を持つ内湾における潮汐 残渣流の実験, 土木学会第 41 回年次講演会概要集, pp. $677 \sim 678,1986$.

12）富永政英：海洋波動一一基礎理論亡観測成果一一，共立 出版, pp. 471 527, 1976 .

13) 寺本俊彦編：海洋物理学 I (海洋学講座 1), 東京大学出版 会, pp. 93 130, 1980 .

14）堀川清司編：海岸環境工学——海岸過程の理論・観测 · 予測方法一一, 東京大学出版会, pp. 92 96, 1985.

15）鷲見栄一：浅海域の海底境界層と物質の動き，沿岸海洋 研究ノ一ト, 第 18 巻, 第 2 号, pp. 88 99, 1981.

(1987.9.24 • 受付) 